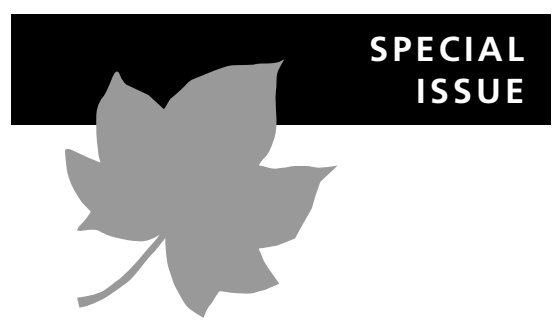

\title{
Spatial heterogeneity, land use and conservation in the cerrado region of Brazil
}

\author{
J. F. Silva ${ }^{1,2 \star}$, M. R. Fariñas ${ }^{2}$, J. M. Felfili ${ }^{3}$ and C. A. Klink ${ }^{4}$
}

${ }^{1}$ Center for International Development, Harvard University, Cambridge, MA, USA, ${ }^{2}$ Instituto de Ciencias Ambientales y Ecologicas (ICAE), Facultad de Ciencias, Universidad de Los Andes, Merida, Venezuela, ${ }^{3}$ Departamento de Engenharia Florestal, Universidade de Brasília CP 04357, Brasília, DF, Brazil and ${ }^{4}$ Departamento de Ecologia, Universidade de Brasília, DF, Brazil

\footnotetext{
${ }^{*}$ Correspondence: Juan F. Silva, ICAE - Facultad de Ciencias, Universidad de Los Andes, Merida, Venezuela.

E-mail: juan_silva004@hotmail.com
}

\begin{abstract}
Aim This paper presents a spatial classification of the environmental and ecological diversity of the cerrado region of Brazil, as well as an appraisal of the levels of conversion to agriculture and of the extent of land protection.

Location The cerrado region of Brazil, located in the centre of Brazil, occupies c. 2.5 million square kilometres. Our study area represents roughly $85 \%$ of the total. This ecologically heterogeneous region is dominated by savannas, but also contains several types of forests and xerophytic communities that often form mosaics with the savannas. Its high biodiversity is seriously threatened by the accelerated process of conversion to agriculture and a deficiency in the extent and the representativeness of protected areas.
\end{abstract}

Methods We selected 124 land systems from a previous study of the lowlands of South America. The maps were digitized and 41 parameters, where environmental information was available, were used to build a matrix. A cluster analysis was then performed and the results used to classify the land systems into units at two scales. The larger units, characterized by the dominant landform and vegetation, were considered as landscape units. Within each of these, smaller units called ecological units were defined by the physiognomy and phenology of the dominant vegetation, topography and drainage. Using GIS, we mapped the resulting ecological units and incorporated the information on land use from the municipal agricultural census of 1996. In addition, data on the extent of protected land units was used to assess the status of land protection in each ecological unit.

Results Five landscape units and 15 ecological units were identified, mapped and explained. These units were not continuous but were represented by disjunct patches located in different parts of the study region. Brief descriptions are given including the geographical locations and dominant ecological features. They also include the extent of land conversion to agriculture (1996 census figures) in each of the various patches as well as the number and area of units of conservation.

Main conclusions The high level of land conversion to agriculture is a major threat to the conservation of the remarkable biodiversity of the cerrado region. This, together with the poor status of land protection, represents the major environmental problem facing this region. However, the fact that areas with similar general ecological conditions have a disjunct distribution is important for conservation purposes, even though the details of floristic similarities and biogeographic influences have still to be worked out. Our detailed spatial classification has made this disjunction clearly apparent and has allowed us to map ecologically similar areas accurately. This allows the evaluation of the status of these areas in terms of land use and land protection and may be used in the design of conservation strategies. 


\section{Keywords}

Biodiversity, cerrado, heterogeneity, land cover, landscape, savanna, South America.

\section{INTRODUCTION}

The cerrado region occupies the Central Region of Brazil for a total of $c$. 2.5 million square kilometres. Its area includes a high environmental diversity of soil types, geology, geomorphology and climate, and contains a heterogeneous assortment of vegetation types. Most of this region consists of seasonal savannas where corridors of mesophytic evergreen forest occur along the rivers (gallery forests). Other kinds of vegetation occur such as hyperseasonal savannas (veredas) on poorly drained soils, dry montane savannas (campo rupestre), as well as different types of seasonal forests such as deciduous and semi-deciduous forests or semi-evergreen forests. Semi-evergreen and other forests are found in close contact with savanna vegetation, sometimes forming intricate mosaics, sometimes covering extended areas. Forest-savanna boundaries are an important part of the biodiversity of this region, with many species depending on the presence of forest and savanna side by side.

Due to its large area, environmental heterogeneity and proximity to other tropical biomes, the cerrado biome has a rich, and until recently, largely unappreciated biodiversity. Mendonça et al. (1998) listed 6429 native species of vascular plants, which makes the cerrado flora the most diverse among the world's tropical savannas. There is also high diversity at the level of genera (1144) and families (170) of vascular plants. Most of these species exhibit characteristic morphological and physiological adaptations to the climatic and edaphic conditions that prevail in the region (see also M.D. Bitencourt et al., unpublished). Plant species are not evenly distributed. A recent floristic survey revealed that of the 951 woody species identified in 376 cerrado locations, c. $35 \%$ were restricted to a single location and that no species was found in all areas (Ratter et al., 2003). Other groups of organisms are generally less well known but evidence shows that there is usually high species richness. For instance, 101 lichen species were recorded in six experimental fire plots in Brasilia (Mistry, 1999). Shannon's alpha diversity index is above 3 nats individual ${ }^{-1}$ for most vegetation types at all layers (Felfili et al., 1994, 1997, 2001; Filgueiras et al., 1998; Felfili \& Silva, 2001; Munhoz, 2003), and reaches 3.5-4 nats individual ${ }^{-1}$ in most gallery forests (Felfili, 1995: Sampaio et al., 2000; Silva et al., 2001; Marimon et al., 2002). When Shannon's index is used with $\log _{e}$ the units are nats individual ${ }^{-1}$; other units result from using different log bases (for more details see Magurran, 1998).

To understand the current landscape of the cerrado it is important to consider modern agricultural expansion. Until the mid-1950s, the lack of communications or highways constrained any significant commercial development. This state of affairs changed drastically after the construction of Brasilia, in the heart of the cerrado region, when highways and railways linking the new capital to the main Brazilian cities were built. Furthermore, government policies gave a large boost to the modernization of agriculture and land transformation; stimulated by subsidized credit, tax breaks and the development of new technologies (Klink et al., 1995; Klink \& Moreira, 2002). To date, around 50\% of the cerrado region has already been transformed into areas of intensive arable crop agriculture and pastures planted with African grasses. There has been a notable increase in the yield of export products, mainly soybeans. The environmental modification brought about by commercial farming in the cerrado is extensive and consists of landscape fragmentation, loss of biodiversity, biological invasion, soil erosion, water pollution, changes in the fire regime, land degradation and intensive use of chemicals (Klink et al., 1995; Klink \& Moreira, 2002).

This enormous and rapid transformation has great implications for the regional ecology. Many cerrado trees and shrubs have deep roots that enable them to explore deep soil water (Meinzer et al., 1999; Oliveira, 1999; Silva, 2003), allowing the maintenance of a flux of water from the soil to the atmosphere even during the dry season. The replacement of deep rootedplants by shallow-rooted crops and pastures can potentially modify the regional evapotranspiration. Deep roots also represent a large stock of soil carbon. In the cerrado up to $71 \%$ of the living phytomass is underground (Felfili \& Silva, 1993, 2001; Castro, 1994; Felfili et al., 1997, 2001; Castro \& Kauffman, 1998; Aduan, 2003). Ratter et al. (2003) compared a great number of cerrado vegetation samples covering large areas of the region by using techniques of multivariate analysis and calculating similarity indices and they found consistent phytogeographical patterns. The knowledge derived from such studies is essential for the design of conservation strategies. However, there is a lack of detailed spatial information, which is needed in order to evaluate the impacts of land conversion to agriculture and the extent of land protection on the different ecosystems of this region. This is probably the result of the difficulties and costs involved in mapping the ecological diversity of such a heterogeneous region.

An important study documenting the spatial heterogeneity of the lowlands of tropical America is that by Cochrane et al. (1985). They identified, characterized and mapped land systems following the approach of Christian \& Steward (1953), who defined a land system as an area, or a group of areas, with a recurrent pattern of climate, landscape and soils. This study has already been used by Fisher \& Thomas (2004) to estimate carbon stocks in the lowlands of tropical South America. In order to contribute to the study of the ecological 
heterogeneity of this region using a spatial approach, we used the results of Cochrane et al. to define, characterize and map ecological units. Furthermore, we documented the extent of land conversion as well as the extent of protected land in each unit.

\section{METHODS}

Nine maps of the cerrado region (scale $1: 2,000,000)$ from Cochrane et al. (1985) were digitized. A total of 124 land systems from that study were mapped and represent our study area. In a few cases, land systems were mapped in the study by Cochrane et al. but they lack any supporting information; thus they appear as empty areas in our maps. We modified the boundaries of the study area in order to include the whole of each municipality, according to the map of municipalities from IBGE-SIDRA (2003). This was done to avoid the inconvenience of fragmented municipalities and allow the use of municipal census data.

Information from the land systems in the Cochrane et al.'s study was then used to prepare a matrix, with a total of 41 variables, including slope, vegetation composition, and soil physical and chemical properties (Table 1). The matrix was subjected to a cluster analysis using Ward's method, also known as the error sum of squares, with PC-ORD4 (McCune \& Mefford, 1999). The resulting clusters were mapped using ArcView GIS 3.2 (Environmental Systems Research Institute, Inc., Redlands, CA, USA). The interpretation of the cluster

\begin{tabular}{|c|c|c|}
\hline No. & Variable & Unit \\
\hline 1 & Flat land & $\%$ \\
\hline 2 & $<8 \%$ slope & $\%$ \\
\hline 3 & $8-30 \%$ slope & $\%$ \\
\hline 4 & $>30 \%$ slope & $\%$ \\
\hline 5 & Altitude & $\mathrm{m}$ \\
\hline 6 & Poorly drained savannas & $\%$ \\
\hline 7 & Grassland + grassland and shrubs & $\%$ \\
\hline 8 & Open, well drained savanna & $\%$ \\
\hline 9 & Dense savanna & $\%$ \\
\hline 10 & Dense woodland savanna (cerradão) & $\%$ \\
\hline 11 & Tropical rain forest & $\%$ \\
\hline 12 & Semi-evergreen seasonal forest & $\%$ \\
\hline 13 & Semi-deciduous seasonal forest & $\%$ \\
\hline 14 & Scrubland (caatinga) & $\%$ \\
\hline 15 & Other types of vegetation & $\%$ \\
\hline 16 & Soil depth & 4 categories \\
\hline 17 & Hydraulic conductivity & 3 categories \\
\hline 18 & Drainage & 3 categories \\
\hline 19 & Moisture holding capacity & 3 categories $\left(\mathrm{mm} 100 \mathrm{~cm}^{-1}\right.$ soil depth) \\
\hline 20 & Moisture regime & 3 categories (no. of dry months) \\
\hline 21 & Topsoil texture & 5 textural categories \\
\hline 22 & Subsoil texture & 5 textural categories \\
\hline 23 & Topsoil coarse material & 3 categories $(\%)$ \\
\hline 24 & Subsoil coarse material & 3 categories $(\%)$ \\
\hline 25 & Topsoil pH & 3 categories \\
\hline 26 & Subsoil pH & 3 categories \\
\hline 27 & Topsoil al saturation & 5 categories $(\%)$ \\
\hline 28 & Subsoil al saturation & 5 categories $(\%)$ \\
\hline 29 & Topsoil exchangeable al & 4 categories $\left(\mathrm{mol}_{\mathrm{c}} 100 \mathrm{~g}^{-1}\right.$ soil $)$ \\
\hline 30 & Subsoil exchangeable al & 4 categories $\left(\mathrm{mol}_{\mathrm{c}} 100 \mathrm{~g}^{-1}\right.$ soil $)$ \\
\hline 31 & Topsoil exchangeable $\mathrm{Ca}$ & 4 categories $\left(\mathrm{mol}_{\mathrm{c}} 100 \mathrm{~g}^{-1}\right.$ soil $)$ \\
\hline 32 & Subsoil exchangeable $\mathrm{Ca}$ & 4 categories $\left(\mathrm{mol}_{\mathrm{c}} 100 \mathrm{~g}^{-1}\right.$ soil $)$ \\
\hline 33 & Topsoil total exchangeable bases & 4 categories $\left(\mathrm{mol}_{\mathrm{c}} 100 \mathrm{~g}^{-1}\right.$ soil $)$ \\
\hline 34 & Subsoil total exchangeable bases & 4 categories $\left(\mathrm{mol}_{\mathrm{c}} 100 \mathrm{~g}^{-1}\right.$ soil $)$ \\
\hline 35 & Topsoil ECEC & 4 categories $\left(\mathrm{mol}_{\mathrm{c}} 100 \mathrm{~g}^{-1}\right.$ soil $)$ \\
\hline 36 & Subsoil ECEC & 4 categories $\left(\mathrm{mol}_{\mathrm{c}} 100 \mathrm{~g}^{-1}\right.$ soil $)$ \\
\hline 37 & Topsoil organic matter & 4 categories $\left(\mathrm{mol}_{\mathrm{c}} 100 \mathrm{~g}^{-1}\right.$ soil $)$ \\
\hline 38 & Subsoil organic matter & 4 categories $\left(\mathrm{mol}_{\mathrm{c}} 100 \mathrm{~g}^{-1}\right.$ soil $)$ \\
\hline 39 & Topsoil P & 4 categories (p.p.m.) \\
\hline 40 & Subsoil P & 4 categories (p.p.m.) \\
\hline 41 & Soil P fixation & 3 categories \\
\hline
\end{tabular}

Table 1 List of variables used for the cluster analysis; units and values taken from Cochrane et al. (1985) 
analysis was conducted based on the field experience of the authors and using additional information from vegetation and soil maps (IBGE, 1992). As a result, we produced maps of major landscapes and their component ecological units, and a description of each one. The 'Ecological Units' (EUs) used here can be defined as areas with the same dominant features in terms of physiognomy and phenology of vegetation, topography and drainage. They are clustered into major units that share the same dominant landform and major type of vegetation that we call here 'Landscape Units' (LUs).

In parallel with the above, we used information from the agricultural census of Brazil (IBGE, 1996) to prepare a map of land use in each municipality of the study region. This map was then used to estimate the degree of land conversion within each ecological unit. Data were restricted to the total area converted to agriculture, total area in crops (annual and permanent) and total area in cultivated pastures. Information on protected areas (national and state parks and ecological reserves) was used to estimate total area under protection (IBGE, 1995; IBAMA, 2002a,b). Estimates of land conversion are from the 1996 census (IBGE, 1996).

\section{RESULTS}

\section{Landscape diversity}

The main results of the cluster analysis and interpretation are summarized in Fig. 1. Fifteen homogeneous clusters were found using only $10-20 \%$ of the information and, with only minor modifications, were finally considered as Ecological Units (EUs). One of these units (5A) remains separate until all the information is used. It corresponds to one of the major landscape units (LUs), the floodplains, dominated by seasonally flooding savanna and is identified in Fig. 1 as Branch B. The other 14 clusters are grouped into four major landscapes units, using c. $40-60 \%$ of the information, and merge in Branch A after $75 \%$ of information is used. Branches A and B are grouped only at the $100 \%$ information level. Topography, drainage, vegetation physiognomy and phenology appear as the basic traits clustering the original land systems.

The five landscapes units (Fig. 2) are: (1) well-drained plains and plateaus dominated by savannas, with semi-deciduous forests and grasslands as secondary vegetation types; (2) hilly terrain dominated by savanna with deciduous forest and grasslands as a secondary types; (3) plains dominated by deciduous and semi-deciduous forests with dense savanna as a secondary type; (4) plains with evergreen, semi-deciduous, and other forests; and (5) poorly drained lowlands dominated by seasonally flooding savannas. Oxisols are predominant in LUs 1 and 2. These soils are well drained with high hydraulic conductivity, deep, predominantly clayey or loamy and dystrophic, being acidic with a high aluminium content. In LUs 3 and 4, alfisols and oxisols are the dominant orders. These are also well drained with medium values of hydraulic conductivity, deep, with mostly loamy topsoil and clayey subsoil, but heterogeneous in aluminium content with low levels in some areas. They are mostly mesotrophic. In LU 5, soils are mostly ultisols, but alfisols and entisols are also important. Hydraulic conductivity is low and drainage is poor. Topsoil is loamy and subsoil clayey, some are high in aluminium, others are low and mostly mesotrophic.

\section{Ecological Units (EU)}

The fifteen EUs are mapped in Fig. 3. They are identified by the number corresponding to the LU to which they belong and by a letter. Below we present a brief description of each unit, including land conversion and status of land protection. Table 2 condenses the dominant features of each EU adding edaphic features that are not included in the description.
Figure 1 Diagrammatic representation of the results of the cluster analysis (see Table 2), showing the five clusters defined as landscape units and the 15 clusters defined as ecological units. A brief description of the dominant features and the level of information used are included.

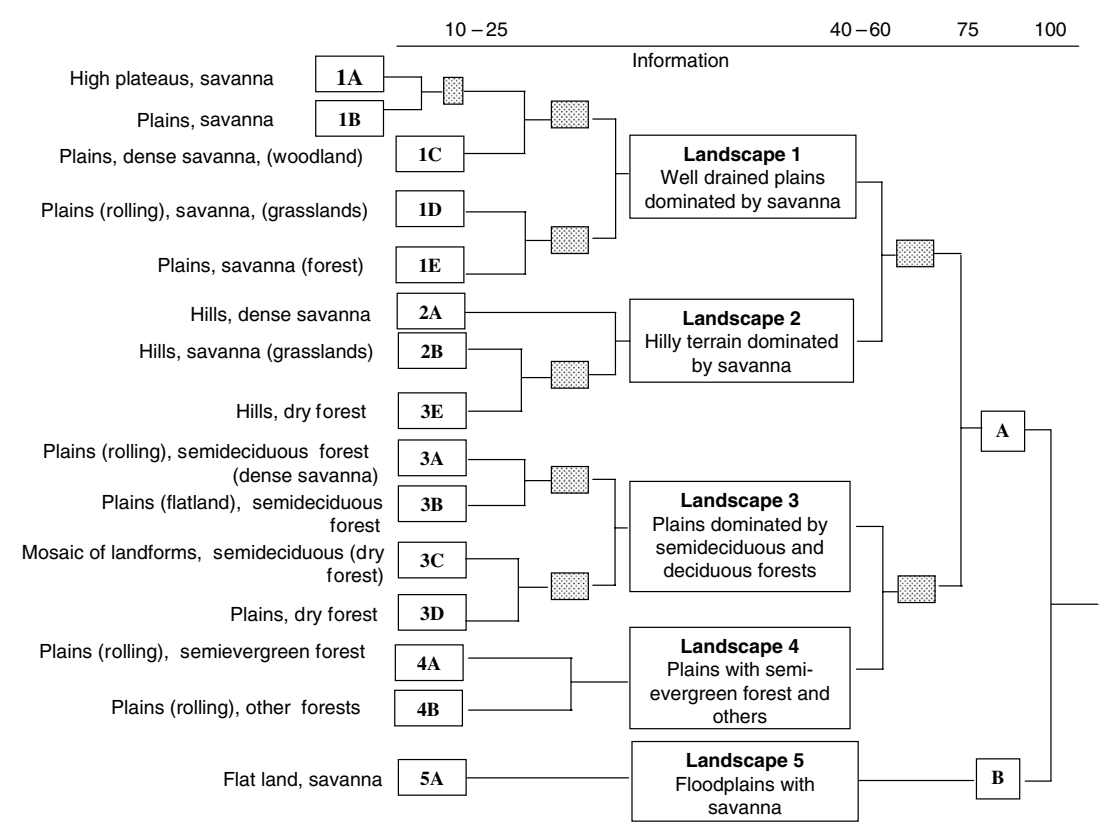




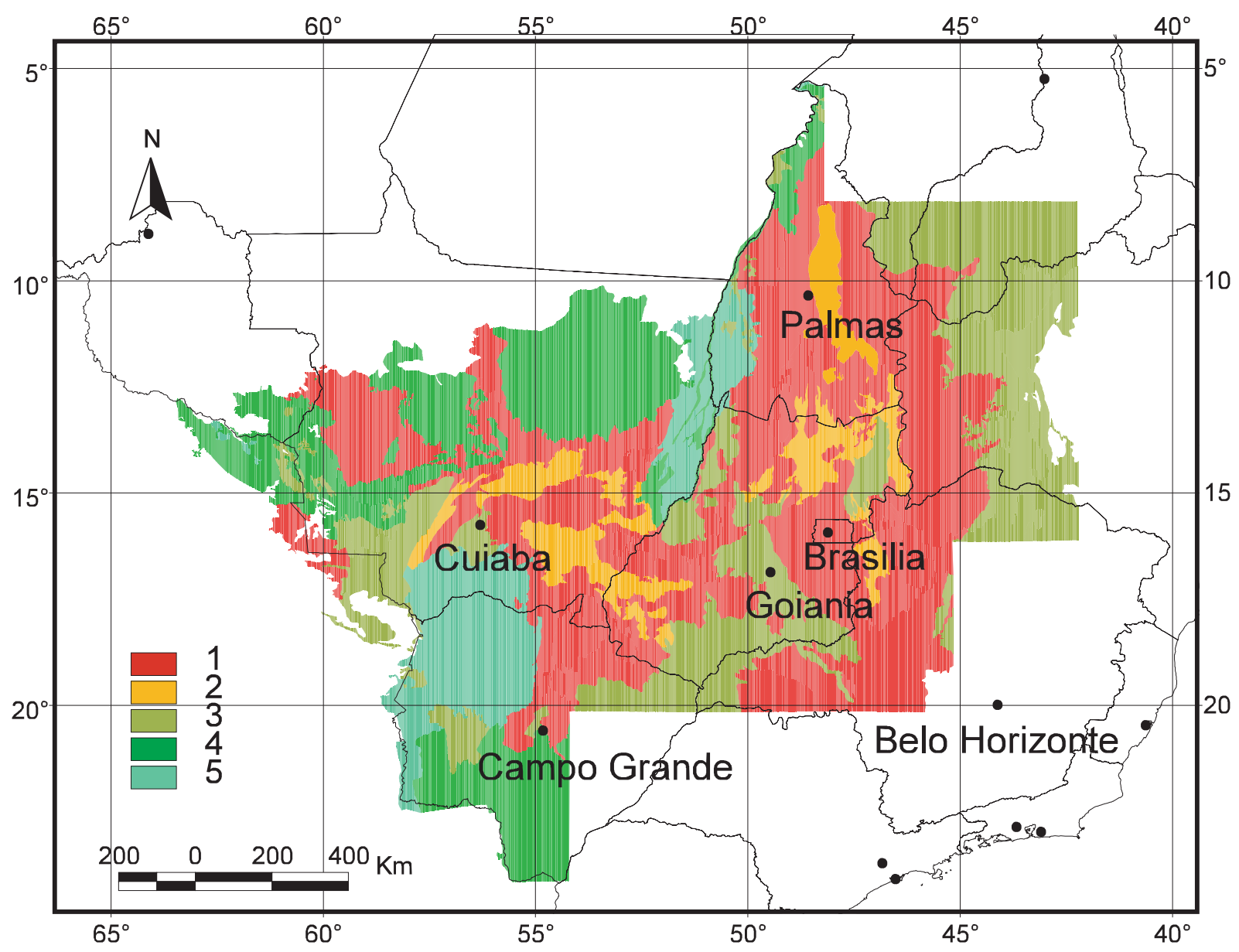

Figure 2 Map of the five landscape units in the study region. (1) Well-drained plains and plateaus dominated by savannas, with semideciduous forests and grasslands as secondary vegetation types; (2) hilly terrain dominated by savanna with deciduous forest and grasslands as secondary types; (3) plains dominated by deciduous and semi-deciduous forests with dense savanna as secondary type; (4) plains with evergreen, semi-deciduous, and other forests; and (5) poorly drained lowlands dominated by seasonally flooding savannas. State boundaries and main cities are shown.

\section{Ecological Unit $1 \mathrm{~A}$}

This contains all high plateau savannas in the region (above $600 \mathrm{~m}$ a.s.l.). The dominant native vegetation is dense savanna (cerrado), but open savanna (campo cerrado), gallery forests and some deciduous forests are also found. The landscape is mostly plain but changes to rolling terrain toward the more eroded borders of the plateaus. Its total area is $c .173,000 \mathrm{~km}^{2}$, and is formed by two main blocks differing in altitudinal range, the eastern block being higher. The western block is located in the States of Goiás and the south-eastern portion of Mato Grosso. The eastern block is located in Goiás, Minas Gerais and the Federal District (DF).

As a whole, $38 \%$ of the land has been converted for agricultural purposes, but the two blocks differ in the extent of conversion: $53 \%$ in the west and $31 \%$ in the east. Furthermore, variation is high between municipalities in both blocks, reaching as high as $80 \%$ in the west and as low as $15 \%$ in the east. Protected areas comprise $1.1 \%$ of the total area of this unit. In the Federal District the main protected areas are: the Brasília National Park $\left(300 \mathrm{~km}^{2}\right)$; the contiguous Brasília Botanical Garden, IBGE Ecological Reserve, and the University of Brasília's Fazenda Água Limpa Research Station (which together comprise a protected area of nearly $300 \mathrm{~km}^{2}$ ); the Águas Emendadas Ecological Station $\left(c .250 \mathrm{~km}^{2}\right)$ draining into three different major basins of the region (Araguaia-Tocantins, São Francisco and ParanáParaguay); finally, a large portion of the Chapada dos Veadeiros National Park (c. $946 \mathrm{~km}^{2}$ ).

\section{Ecological Unit $1 B$}

This ecological unit occupies the second level, below the $1 \mathrm{~A}$ plateaus, with altitudes between 550 and $700 \mathrm{~m}$ a.s.l., although one block in Tocantins is only $350 \mathrm{~m}$ a.s.l. It is predominantly plain with some rolling terrain. The vegetation is mostly dense savanna intertwined with some dense woodland (cerradão) and semi-deciduous forest. With a total area of $c .146,000 \mathrm{~km}^{2}$, it is widely distributed in several large blocks forming an arch from northern Tocantins, to central Goiás, to eastern Mato Grosso and northern Mato Grosso do Sul (Fig. 3). 


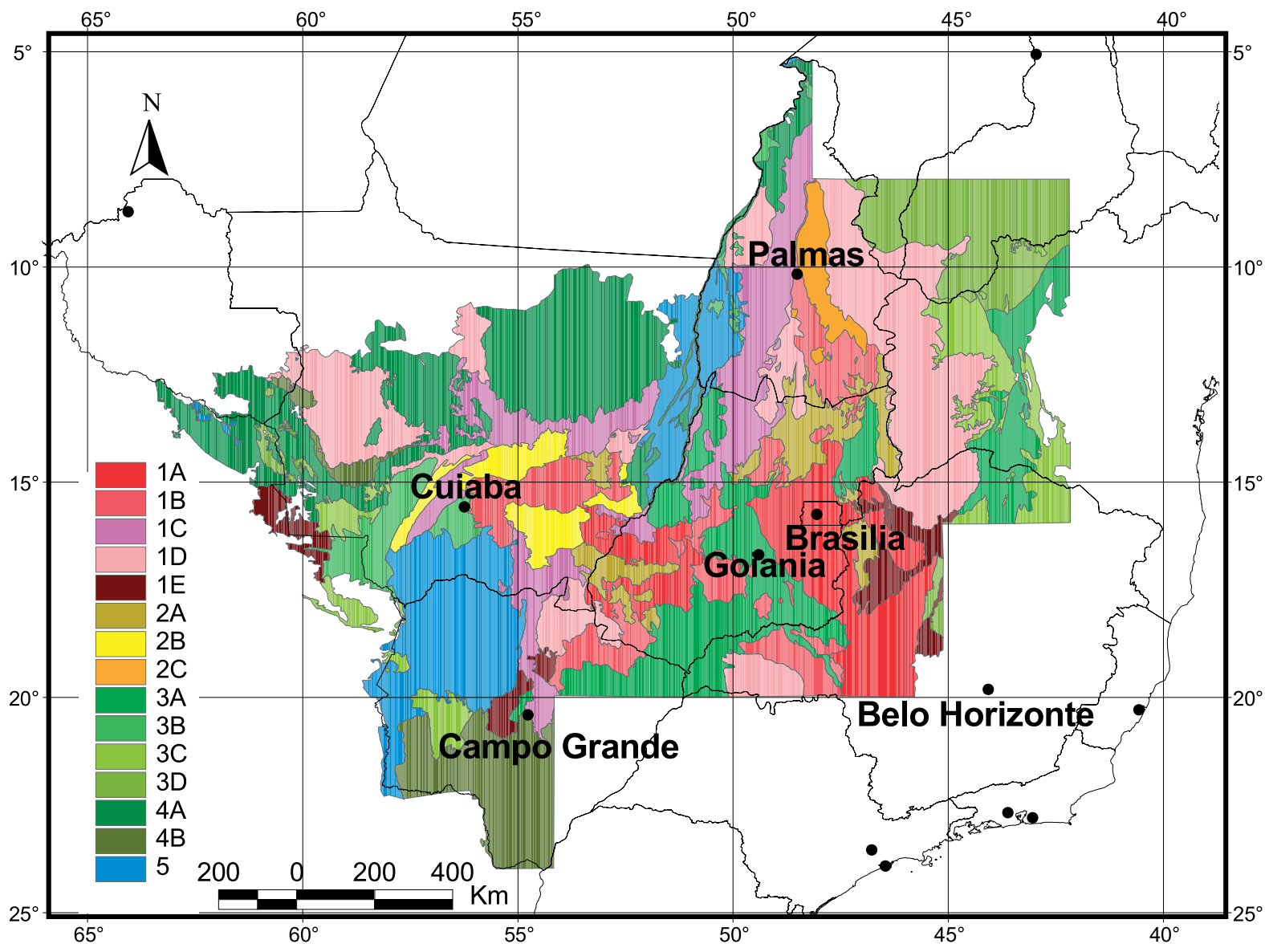

Figure 3 Map of the 15 ecological units in the study area. State boundaries and main cities are shown.

About $40 \%$ of this unit has been converted to different land uses, but differences between blocks are important. For instance, native vegetation of dense savanna and woodlands covers extensive areas along the eastern side of the Tocantins River valley ('Oriental do Tocantins' in Tocantins State), including the lower Paraná River and in northern Goiás in the heights of the Tocantins River, where only $14 \%$ of the area is used for agriculture, mostly for introduced pastures. In contrast, conversion to agriculture has been higher in southern Mato Grosso (38\%), southern Goiás and eastern Mato Grosso do Sul (63\%) along the high Paranaíba basin.

Thus, whilst the native savannas and forests have mostly been cleared in the southern regions, it is still present in large expanses in the northern areas, offering an opportunity to protect some of these habitats. This is particularly relevant since only one National Park is located within this unit: the Chapada dos Guimarães National Park $\left(330 \mathrm{~km}^{2}\right)$ in southern Mato Grosso, which represents $0.23 \%$ of the unit area.

\section{Ecological Unit $1 C$}

These plains represent a third level of altitude, mostly between 200 and $400 \mathrm{~m}$ a.s.l. and only marginally up to $800 \mathrm{~m}$ a.s.l. Plains are the dominant feature of the landscape, which is covered with mosaics of dense and open savanna. The total area is approxi- mately 190,000 $\mathrm{km}^{2}$, distributed in three major blocks and a few smaller disjunct areas forming two arches curving from NE to SW, separated by the Araguaia and Rio das Mortes rivers (Fig. 3). The smaller arch (in Mato Grosso) forms the boundary with the transitional forests of the Xingú basin. The larger arch borders the higher savanna regions (Tocantins, western Goiás, southern Mato Grosso and Northern Mato Grosso do Sul).

Less than $20 \%$ of the area in Mato Grosso is used for agricultural purposes, while in Tocantins conversion has reached 58\%, and in Goiás it exceeds $60 \%$. The southern block, a narrow stretch from Mato Grosso to Mato Grosso de Sul, has $45 \%$ of its area transformed mostly into pasturelands.

About half of this unit is in the states of Goiás and Mato Grosso do Sul, where intensive agricultural use is underway, creating mosaics of croplands and native vegetation. However, large expanses of natural vegetation remain almost intact, especially in Tocantins and northern Mato Grosso. There is no national park or any other major protected area within this unit.

\section{Ecological Unit 1D}

These plains are located at three main levels: high plains (700$800 \mathrm{~m}$ a.s.l.), intermediate plains (500-600 m a.s.l.) and lower plains (300-400 $\mathrm{m}$ a.s.l.). The landscape is mostly plain with some rolling terrain, covered by a mosaic of savannas with 


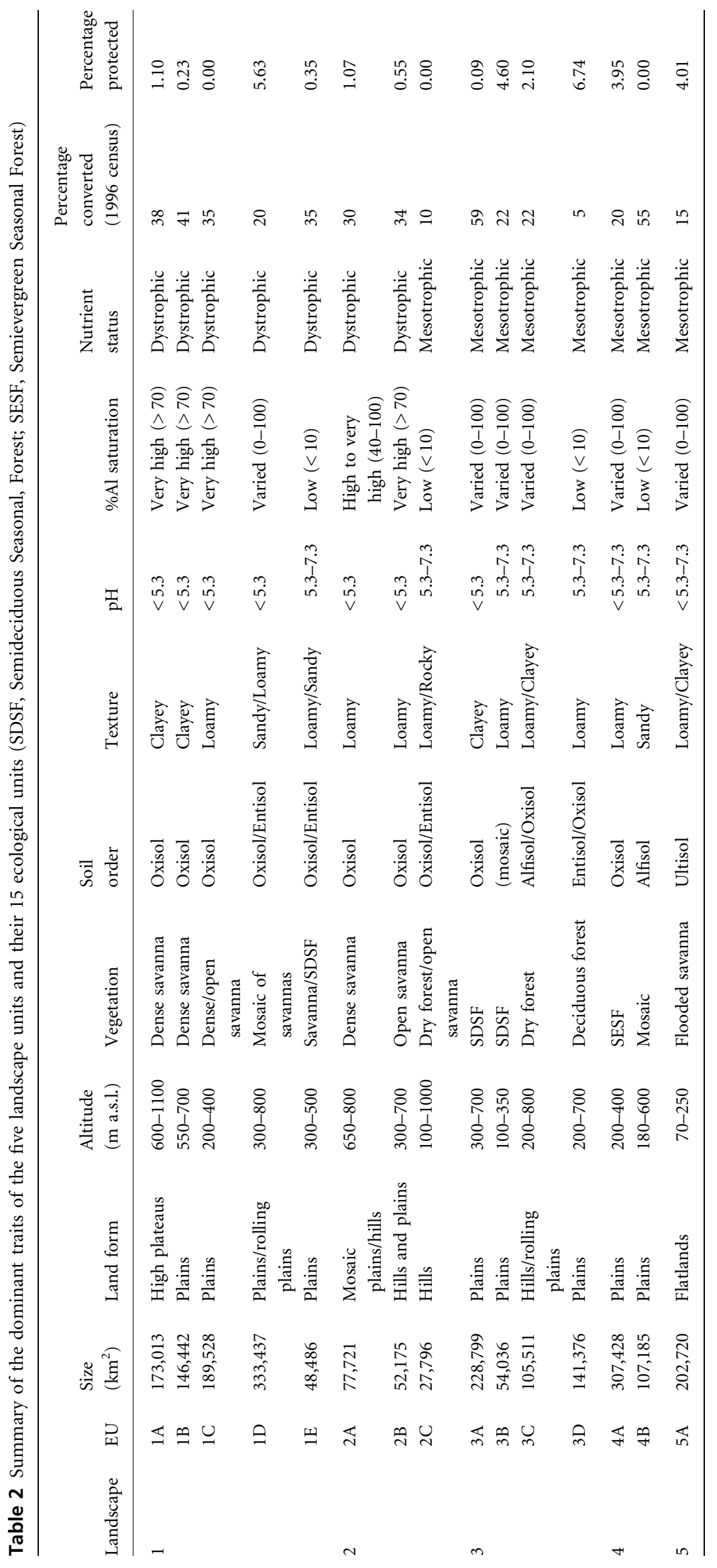


varying tree density, ranging from open grassland to dense savanna. Some denser savannas and woodlands occur occasionally.

The total area is $c .333,000 \mathrm{~km}^{2}$, fragmented in nine blocks of variable size (Fig. 3). Two main blocks are identified: the largest one extends from northern Minas Gerais, through western Bahia into Tocantins and Piauí. The second large block is located in western Mato Grosso. The remaining seven blocks are smaller and spread over the study area. Agricultural conversion varies widely between blocks: in the eastern block it is only $9 \%$, whereas in Mato Grosso it is $16 \%$ and in Tocantins $30 \%$. In the southern blocks conversion reaches $60 \%$, with some municipalities exceeding $75 \%$.

There are several important protected areas in this unit: the Serra Geral de Tocantins' Ecological Station $\left(7163 \mathrm{~km}^{2}\right)$, which is contiguous to the Jalapão State Park $\left(1588 \mathrm{~km}^{2}\right)$; in southern Goiás, most of the Emas National Park $\left(1330 \mathrm{~km}^{2}\right)$ is included; the Grande Sertão Veredas National Park $\left(840 \mathrm{~km}^{2}\right)$ and the Cavernas do Peruaçú National Park $\left(568 \mathrm{~km}^{2}\right)$, both in the State of Minas Gerais; and the Nascentes do Rios Parnaiba National Park (7298 sq $\mathrm{km}^{2}$ ) located in the convergence of Tocantins, Maranhão, Piauí and Bahia. This unit has the largest proportion of protected area in the cerrado biome, representing $6.4 \%$ of its total area.

\section{Ecological Unit $1 E$}

This unit is predominantly plain, with altitudes ranging from 300 to $525 \mathrm{~m}$ a.s.l. and mosaics of open savanna and semideciduous forest as the dominant vegetation. The total area of $48,486 \mathrm{~km}^{2}$ is distributed in three states: Minas Gerais, partially occupied by the Tres Marias dam in the upper São Francisco River; in the central region of Mato Grosso do Sul, bordering the Pantanal; and in Mato Grosso, extending into Bolivia.

The areas in Minas Gerais are less affected by agriculture, with only $23 \%$ of the land converted, mostly to pasture lands. In contrast, almost $70 \%$ of the areas in Mato Grosso do Sul are converted, leaving very little native forest or savannas.

Two Minas Gerais State biological reserves are located in this unit near the Urucuia river: the Sagarana-Logradouro and the Sagarana-Mata Seca, which add up to $c .170 \mathrm{~km}^{2}$. The unit is also represented in nearby Bolivia, still within the Brazilian Shield, where it is much better preserved.

\section{Ecological Unit $2 \mathrm{~A}$}

This unit, with $77,000 \mathrm{~km}^{2}$, is predominantly hilly in the eastern blocks and a mosaic of rolling terrains, plains and hills in the west, reaching altitudes of $650-800 \mathrm{~m}$. The dominant native vegetation is dense savanna, sometimes forming mosaics with open savanna and native grasslands. Most of the area is located in the State of Goiás, where several blocks of variable size are found in the north-east, extending to Tocantins in the north and Minas Gerais to the east (Fig. 3). Further tracts are located in southwestern Goiás, extending into Mato Grosso in the upper
Araguaia river. Finally a small block is found in Mato Grosso, in the Canarana micro-region of the upper Xingu basin.

Land conversion is only $23 \%$ in northeastern Goiás, $33 \%$ in Mato Grosso and it reaches $45 \%$ in southwestern Goiás. In all cases, pasturelands with introduced African grass species are predominant. Only one protected area, the Chapada dos Veadeiros National Park $\left(828 \mathrm{~km}^{2}\right)$ is partially contained in this unit, comprising $1.1 \%$ of the total unit area.

\section{Ecological Unit $2 B$}

This is a relatively small ecological unit of $c .52,000 \mathrm{~km}^{2}$, located in the State of Mato Grosso, north of the Pantanal wetland, near the capital city of Cuiabá (Fig. 3). The landscape in this unit is predominantly hilly, but there are areas with mosaics of hills, rolling terrain and plains. The altitude varies between 300 and $700 \mathrm{~m}$ a.s.l. The native vegetation is a mosaic of open savanna and grassland, but there are also some areas with mosaics of savanna, grassland, semi-deciduous and evergreen forests. Soils are well drained, except in areas where grasslands dominate and present superficial soils with seasonal water logging.

In the areas located toward the southeast of Mato Grosso, $45 \%$ of the land has been converted to pastures and crops. In the central south, $23 \%$ of the area has also been converted. The Ecological Station Serra das Araras $\left(287 \mathrm{~km}^{2}\right)$ is located in this area, representing $0.55 \%$ of the total unit area.

\section{Ecological Unit 2C}

This small unit $\left(27,000 \mathrm{~km}^{2}\right)$, located in the eastern portion of the State of Tocantins (Fig. 3), is predominantly hilly, especially to the south where some hills reach $1000 \mathrm{~m}$ a.s.l. Altitudes decrease progressively toward the north, reaching $100 \mathrm{~m}$ in the rolling plains of the Sono and the Tocantins rivers. The hills are covered with dry forest and scrub but open savanna is found on the northern plains.

Since most of the unit is rough terrain, agricultural activities are not extensive. Only $10 \%$ of the area has been converted, mostly to pasturelands. In less hilly terrain, such as in Aparecida do Rio Negro (Porto Nacional), conversion is more extensive, reaching up to $33 \%$ of the land. There are no protected areas within this unit.

\section{Ecological Unit $3 A$}

Plains, with some rolling terrain, dominate the landscape. Native vegetation is a mosaic of semi-deciduous forest and dense woodlands with some dense savanna, especially in the north-east. This unit covers an area of c. $229,000 \mathrm{~km}^{2}$, mostly in the State of Goiás where it occupies north-eastern and north-western areas, as well as more central and southern areas (Fig. 3). It extends to Minas Gerais (Triangulo Mineiro), the north-east of Mato Grosso do Sul and marginally into São Paulo. A single large block reaches from northern Minas Gerais to central Bahia, along the São 
Francisco river. The Sobradinho dam is built on this land. Most of the vegetation has been modified by agriculture. The least transformed area is the eastern block, with $17 \%$ of land converted to crops and pasture. The upper Paranã valley, with $30 \%$ conversion, is important in terms of endemism. Silva \& Bates (2002) described this area as one of the three areas of bird endemism in the cerrado region. Of the remainder, $60 \%$ has been converted, mostly to pastureland. In some municipalities conversion reaches up to $80 \%$.

Only two small State Parks exist in the whole unit: the Altamira de Moura Pacheco near Goiânia, and the Serra das Caldas Novas in southern Goiás (totalling c. $200 \mathrm{~km}^{2}$ ).

\section{Ecological Unit $3 B$}

These are lower plains originally covered almost totally with semi-deciduous forest, although in some areas it forms mosaics with dense savanna and dry forest, mostly on welldrained soils.

Covering $45,737 \mathrm{~km}^{2}$, the semi-deciduous forest plains consist of two distinct blocks (Fig. 3): a narrow band of terraces in the north along the Araguaia river, projecting into the Amazon Region (difficult to see at the scale of the map), and covered by mosaics of forests with some savanna; towards the southwest, at the edge of the Pantanal in the State of Mato Grosso, and on the plains of the upper Paraguai and the Cuiabá rivers, where savanna and deciduous forest appear together with the semi-deciduous forest. The two blocks have been similarly affected by agriculture, with c. $20 \%$ of the land converted mostly to pastures.

In the Araguaia river, the unit is partially covered by the Araguaia National Park and by the Cantaro State Park, comprising c. $4.6 \%$ of the unit's area.

\section{Ecological Unit 3C}

This unit is a mosaic of hills and rolling plains with semideciduous and deciduous forests. Its total area of c. $105,000 \mathrm{~km}^{2}$ is distributed in several small blocks in the eastern and western borders of the study area.

In the eastern sector (Fig. 3), hilly areas are in the upper São Francisco river and the Pardo river in Minas Gerais, whereas rolling plains occur between the Preto and Grande rivers. Agricultural conversion has taken place in up to $70 \%$ of the land in some areas bordering the São Francisco, but in the rest of this sector it is below 20\%. The Pardo and Verde Grande rivers delimit the northern portion of the Serra do Espinhaço, rich in endemism. Based on data from bird communities, Silva \& Bates (2002) defined this as one of the three sub-areas of endemism for the cerrado region.

In the west, hills and rolling plains are located in the middle Miranda river, as well as in the area between the Sepotuba and Las Petas rivers. Almost $40 \%$ of these lands have been converted, mostly to pasture.

The Santa Barbara State Park $\left(1400 \mathrm{~km}^{2}\right)$ is located in SW Mato Grosso. The $755 \mathrm{~km}^{2}$ Bodoquena National Park is in the southern fringe of the unit, in Mato Grosso do Sul. This is on a peneplain with limestone outcrops. Together they represent $2.1 \%$ of the area of this unit, which is better preserved in the region of the Brazilian Shield that extends into Bolivia.

\section{Ecological Unit 3D}

This unit consists of plains at an altitude of 600-700 m a.s.l., covered almost entirely by dry forest and scrub vegetation. This unit, of over $142,000 \mathrm{~km}^{2}$, is represented by two sets, one on the eastern and the other on the western borders of the region (Fig. 3). The eastern block is located in southern Piauí and Maranhão States. Land conversion here is only $4 \%$ and there are two major national parks: Capivara National Park $\left(1000 \mathrm{~km}^{2}\right)$ and Serra das Confusões National Park $\left(5024 \mathrm{~km}^{2}\right)$. Similar plains are located along São Francisco river in central Minas Gerais. In this area, only c. $10 \%$ of land has been converted to agriculture. The western set is represented by a series of terraces, $200-300 \mathrm{~m}$ high, along the Guapore river and along some tributaries in the border with Bolivia. They appear as a series of islands of dry forest in a matrix of semi evergreen seasonal forest. About 20\% of the land has been converted to agriculture, almost all introduced pastures. The unit extends into the Chiquitania region in Bolivia, where human disturbance is less.

\section{Ecological Unit $4 A$}

This consists mostly of extended plains with some rolling terrain or flatland, 200-400 m a.s.l., covered by semi-evergreen seasonal forest as the dominant vegetation. It is the second largest unit in the region with over $300,000 \mathrm{~km}^{2}$, located along the north-western border of the region, in the contact zone with the Amazonian forests (Fig. 3). It occupies the central region of Mato Grosso, and the southern of Rondônia, and extends to Bolivia. It is also present as a narrow band of forests along the Araguaia river in Tocantins.

The main feature of this unit is that it is a land of contact and transition between major types of vegetation: the savannas to the south, and the rain forest to the north. Agricultural conversion in the unit as a whole is c. $20 \%$, but it is highly variable and spatially fragmented. In some areas, like northern Tocantins and central Mato Grosso, conversion is more important, reaching as high as $80 \%$. These areas form part of the advancing agricultural frontier.

There are several protected areas in this unit: the Ique Ecological Station in Mato Grosso $\left(2000 \mathrm{~km}^{2}\right)$, the Guapore Biological Reserve in Rondônia $\left(6000 \mathrm{~km}^{2}\right)$, and the Serra da Cutía National Park $\left(2836 \mathrm{~km}^{2}\right)$. In addition, there are several indigenous lands partially or totally within the unit. Almost $4 \%$ of the unit area is under protection.

\section{Ecological Unit $4 B$}

These are plains varying in altitude from 180 to $600 \mathrm{~m}$ a.s.l. The original vegetation was a mosaic of mixed forests (from 
evergreen to deciduous) and dense woodland and savanna. Its $100,000 \mathrm{~km}^{2}$ area is located in Mato Grosso and Mato Grosso do Sul, both north and south of the Pantanal (Fig. 3). The unit has been disturbed by human occupation in Mato Grosso do Sul, as more than $60 \%$ of its area has been converted to agriculture. In Mato Grosso, conversion is c. $20 \%$. No major protected areas are located in these lands.

\section{Ecological Unit $5 A$}

Poorly-drained flatlands dominate the landscape $(70-250 \mathrm{~m}$ a.s.l.), with flooding savannas as the dominant vegetation, although in some areas they form mosaics with open forests and small plots of better-drained savanna. This unit differs completely from the others, not only in terms of soils, vegetation, and fauna, but also in the functioning of the ecosystem. Water seasonality is very strong, with large areas being flooded during the rainy season and then becoming very dry during the dry season.

This unit is represented by three areas, as shown in Fig. 3. The largest one (c. $134,000 \mathrm{~km}^{2}$ ) corresponds roughly to the Pantanal wetland and is usually classified separately from the cerrado region. The second block is located in the middle Araguaia river, including Bananal Island. A third smaller block is located in the south-east of Rondônia, on the border with Bolivia, extending into the Guayamerin Plains. Due to the conditions of the terrain, less than $15 \%$ of the unit has been converted to agriculture, almost totally with introduced pastures. The Pantanal and the Araguaia river valley are both considered biologically very rich, and are the site of large national parks: the Pantanal Matogrossense National Park, with an area of $1350 \mathrm{~km}^{2}$ is located in the south-west of Mato Grosso, between the Cuiabá and Paraguai rivers; while the Araguaia National Park, $5577 \mathrm{~km}^{2}$, occupies the northern portion of the Bananal Island. These two national parks represent $3.6 \%$ of the total area of this unit. Silva \& Bates (2002) include the Araguaia river valley as the third major area of endemism for avifauna of the cerrado region.

\section{DISCUSSION}

Using several sources of information we have identified and mapped the ecological heterogeneity of most of the cerrado region of central Brazil at two scales and defined the results as 'landscape units' (LUs) and 'ecological units' (EUs). One main feature of the spatial heterogeneity of the study region is that, in both scales of analysis, we found fragmentation instead of geographical continuity within each unit. At a more detailed scale, the physiognomy of native vegetation is also patchy, with heterogeneous mosaics being frequently found (Eiten, 1972; Felfili \& Silva, 1993; Ratter et al., 2003). This is likely to be a common feature of savanna regions and may have been a deterrent to the earlier attempts at spatial representation of the ecological diversity of the cerrado.

In our classification, drainage, topography and dominant type of vegetation (physiognomy and phenology) were the main discriminant factors. Because soils are affected by these factors, some edaphic traits differ at the scale of the landscape units, but are less important to differentiate between ecological units. Although this region is characterized by an overall geographical gradient in annual rainfall from north-east to south-west, sections of the same ecological units are spread over the entire study area. Cochrane et al. (1985) distinguished three moisture regimes: Aridic with more than six dry months, Ustic with three to six dry months, and Aquic (or Udic) with less than three dry months. Only one EU is predominantly Aridic (3D), the large block in the north-east close to the arid region known as 'Caatinga', and a small block in the Chiquitania region of Bolivia close to the border with Brazil. Two EUs are Aquic (4A, occurring in the north and north-west, and $5 \mathrm{~A}$, occurring in the north and south-west). All the other units are Ustic. It seems that edaphic properties such as hydraulic conductivity and moisture holding capacity are important for this differentiation.

Savannas dominate the study area with $46 \%$ of the total area. Seven EUs are dominated by well drained savannas, although they also have grasslands and forests as patches of varying sizes and as galleries along the rivers. Five of these (in Landscape 1) are on plains and peneplains that occupy c. $900,000 \mathrm{~km}^{2}$ (c. $40 \%$ of the study area). The other two (in Landscape 2) are on mosaics of hills and plains occupying $130,000 \mathrm{~km}^{2}$ ( $6 \%$ of the study area). In these EUs, between $20 \%$ and $40 \%$ of the land has been converted to agriculture, and conservation effort (as represented by conservation units) is scarce. The largest EU (1D) has the lowest average of land conversion $(20 \%)$ and the highest total percentage of land protected $(5.6 \%)$. Savannas liable to flooding are dominant in EU $5 \mathrm{~A}$, and occupy $9 \%$ of the study area.

Forest cover in our study area includes evergreen, semideciduous, deciduous and dry forests. Three EUs are dominated by semi-deciduous forests (3A, 3B and 3C). The first two are on plains and the latter on a mosaic of plains and hills. Together they represent c. $17 \%$ of the study area. A fourth EU (landscape 4,19\% of the study area) is formed by mosaics of evergreen and semi-deciduous forests located in the northern realms of the study area. Two other EUs are dominated by dry forest: $2 \mathrm{C}$ on hills in the north-east, and $3 \mathrm{D}$ on plains located as described above. Together they represent close to $8 \%$ of the study area. As a whole, forests dominate $44 \%$ of the study area, but within these, some areas are usually included as Amazonian formations. The greatest land conversion to agriculture is found in semi-deciduous forest, ranging from $20 \%$ to $60 \%$ conversion, whereas dry forest has the lowest impact with only $5-10 \%$ of land conversion. Although measurement of the impacts of land use change has been restricted to agricultural conversion, other human impacts are important. Extensive cattle ranching on native savannas usually implies deforestation to produce charcoal and to construct fences as well as an increase in the frequency of fires. All these activities substantially modify the physiognomy of native savannas. Equally important has been timber extraction from deciduous and semi-deciduous forests, leading some tree species to local extinction, but these other impacts are very difficult to 
quantify. Moreover, the data used to calculate land conversion are taken from the most recent available census (1996), thus greatly underestimating the degree of conversion.

We have to emphasize the heterogeneity of this region at all scales from landscape to plant communities.

The high level of forest cover within the cerrado region has been overlooked by decision makers who consider only the dominant savanna vegetation in formulating legal regulations. Thus the forest area required by law to be protected from conversion to agriculture in the cerrado is only $20 \%$, in contrast to the $50 \%$ required in Amazonia and in the Atlantic forest.

Savannas of variable tree cover and drainage, forests with different degrees of deciduousness, wet and dry forests, woodlands, palm communities, grasslands, gallery forests combine to form intricate vegetation mosaics. This aspect is important in terms of the biodiversity of different animal groups and allows high beta diversity in the region. The fact that areas with similar general ecological conditions have a disjunct distribution is significant for conservation purposes, although the details of floristic similarities and biogeographic influences have still to be worked out. Our analysis and spatial classification has made this disjunction clearly apparent and has identified the location of ecologically similar areas. This focuses attention on the status of these areas in terms of land use and land protection. However, we have already mentioned some drawbacks to our study in the accurate assessment of the impact of land-use changes. To these, we should add possible errors in the data base of Cochrane et al. (1985), as suggested by Fisher \& Thomas (2004).

As has been made clear by our results, conservation efforts in the cerrado have not achieved international standards or even the level achieved for other Brazilian biomes. While close to $6 \%$ of the Amazon rain forest is under strict protection, for the cerrado only $1.6 \%$ of its area is under protection (Cavalcanti \& Joly, 2002; Arruda, 2003). This represents a major challenge for conservation because transformation of natural ecosystems continues at a rapid pace and, as shown in this paper, the landscape diversity is considerable (with consequent high levels of biodiversity). In some locations large-scale human modification of the landscape has already occurred, such as in the states of Mato Grosso do Sul, Goiás, and São Paulo, and the 'Triângulo Mineiro' in Minas Gerais. In all these places, between $50 \%$ and $92 \%$ of cerrado landscape has already been modified (Cavalcanti \& Joly, 2002).

\section{CONCLUSIONS}

We distinguished and mapped five landscapes predominantly on the basis of topography and drainage, and we also discriminated 15 ecological units using vegetation physiognomy and phenology. Savanna constituted nearly half of the cerrado region, and a further $44 \%$ of the area is covered by different forms of forest. Conversion of natural vegetation to agriculture is widespread and spatially very variable (5-60\%), with the greatest impact occurring in the endangered semideciduous forest. Conservation is at a low level in the cerrado region, with less than $2 \%$ of the original vegetation protected. Our detailed spatial classification has provided an objectively based map of areas of similar general ecological conditions with disjunct distribution within the cerrado. We also indicate the different degrees of conversion to agriculture. These results should stimulate further research on the spatial relationships between land-use change and conservation efforts, in order to improve the estimates of ecosystem modification, and to target areas where conservation efforts would be more effective.

\section{ACKNOWLEDGEMENTS}

We are grateful to the following for financial support: the International Institute for Research on Global Change (IAI) through grant CRN-040 (RICAS); the AVINA Foundation through a grant to the Center for International Development of Harvard University; the Brazilian Ministry of Environment through a grant to C.K., who also acknowledges CAPES-Brazil and University of Maryland at College Park for sabbatical support; FNMA and DFID-UK for funding the projects Biogeography of the Cerrado Biome and Conservation and Management of the Biodiversity of the Cerrado Biome. We thank Edson Sano (EMBRAPA-Brazil), Andrew Mellinger (CID, Harvard University) and Otto T. Solbrig (Harvard University) for their help at various stages of this research. We are grateful to Peter Furley for great help with the final stages of the manuscript.

\section{REFERENCES}

Aduan, R.E. (2003) Respiração de solos e ciclagem de carbono em cerrado nativo e pastagem no Brasil Central. Unpublished Doctorate Thesis, University of Brasília, Brazil.

Arruda, M.B. (2003) Estudo de representatividade ecológica com base na biogeografia de biomas e ecoregiões continentais do Brasil. O caso do bioma cerrado. Unpublished Doctorate Thesis, University of Brasilia, Brazil.

Castro, A.A.J.F. (1994) Comparação florístico-geográfica (Brasil) e fitossociológica (Piauí-São Paulo) de amostras de cerrado. Unpublished Master's Thesis, University of Campinas, Brazil.

Castro, E.A. \& Kauffman, J.B. (1998) Ecosystem structure in the Brazilian cerrado: a vegetation gradient of aboveground biomass, root mass and consumption by fire. Journal of Tropical Ecology, 14, 263-284.

Cavalcanti, R. \& Joly, C. (2002) The conservation of the cerrados. The cerrado of Brazil: ecology and natural history of a neotropical savanna (ed. by P.S. Oliveira and R.J. Marquis), pp. 351-367. Columbia University Press, New York.

Christian, C.S. \& Steward, S.A. (1953) Survey of KatherineDarwin region 1946. Land Research Series I. CSIRO, Australia.

Cochrane, T.T., Sanchez, L.G., Azevedo, L.G., Porras, J.A. \& Garver, C.L. (1985) Land in tropical America. CIAT/ EMBRAPA-CPAC, 3 vols. Cali, Colombia.

Eiten, G. (1972) The cerrado vegetation of Brazil. Botanical Review, 38, 201-341. 
Felfili, J.M. (1995) Diversity, structure and dynamics of a gallery forest in central Brazil. Vegetatio, 117, 1-15.

Felfili, J.M. \& Silva, M.C. (1993) A comparative study of cerrado (sensu stricto) vegetation in central Brazil. Journal of Tropical Ecology, 9, 277-289.

Felfili, J.M. \& Silva, M.C. (eds) (2001) Biogeografia do bioma cerrado. Estudo fitofisionômico na Chapada do espigão Mestre do São Francisco. University of Brasília, Brazil.

Felfili, J.M., Filgueiras, T.S., Haridasan, M., Silva, M.C., Mendonça, R. \& Rezende, A.V. (1994) Projeto biogeografia do bioma cerrado: Vegetação e solos. Cadernos de geociências do IBGE, 12, 75-166.

Felfili, J.M., Silva, M.C., Rezende, A.V., Nogueira, P.E., Walter, B.W.T., Silva, M.A. \& Encinas, J.I. (1997) Comparação florística e fitossociológica do cerrado nas Chapadas Pratinha e dos Veadeiros. Contribuição ao conhecimento ecológico do cerrado (ed. by L. Leite and C. Saito), pp. 6-11. University of Brasília, Brazil.

Felfili, J.M., Mendonça, R.C., Walter, B.M.T., Silva, M.C., Fagg, C.W., Nóbrega, M.G.G., Sevilha, A.C.E. \& Silva, M.A. (2001) Flora fanerogâmica das matas de galeria e ciliares do brasil central. Cerrado: caracterização e recuperação de matas de galeria (ed. by J.F. Ribeiro, C.E.L. Fonseca and J.C. SousaSilva), pp. 195-263. EMBRAPA-CERRADOS, Planaltina, DF, Brazil.

Filgueiras, T.S., Felfili, J.M., Silva, M.C. \& Nogueira, P.E. (1998) Floristic and structural comparison of cerrado sensu stricto vegetation in Central Brasil. Measuring and monitoring forest biological diversity (ed. by F. Dallmeier and J.A. Comiskey), pp. 633-647. Midsomer Norton, UK.

Fisher, M.J. \& Thomas, R.J. (2004) Implications of land use change to introduced pastures on carbon stocks in the central Lowlands of tropical South America. Environment, Development and Sustainability, 6, 111-131.

IBAMA (2002a) Unidades de Conservação Federais. Instituto Brasileiro do Meio Ambiente e dos Recursos Naturais Renováveis. Ministério de Meio Ambiente, Brasília, Brazil.

IBAMA (2002b) Mapas de distribução das Unidades de Conservação em Unidades Federais. Instituto Brasileiro do Meio Ambiente e dos Recursos Naturais Renováveis. Ministério de Meio Ambiente, Brasília, Brazil.

IBGE (1992) Atlas Nacional do Brasil. Instituto Brasileiro de Geografia y Estadistica, Brasília, Brazil.

IBGE (1995) Mapa de Area de Unidades de Conservação. Instituto Brasileiro de Geografia e Estatística. Directoria de Geociências. Sistema de Informação de Recursos Naturais e Meio Ambiente. Brasilia, Brazil.

IBGE (1996) Censo Agropecuário de 1995/96. Sistema de Recuperação Automática (SIDRA), Instituto Brasileiro de Geografia e Estatistica. http://www.sidra.ibge.gov.br/bda/ acervo.

IBGE-SIDRA (2003) Map of municipalities. Sistema de Recuperação Automática (SIDRA), Instituto Brasileiro de Geografia e Estatística. http://www.sidra.ibge.gov.br/bda/ territorio/.
Klink, C.A. \& Moreira, A.G. (2002) Past and current human occupation, and land-use. The cerrado of Brazil: ecology and natural history of a neotropical savanna (ed. by P. Oliveira and R. Marquis), pp. 69-88. Columbia University Press, New York.

Klink, C.A., Macedo, R.H. \& Mueller, C.C. (1995) De Grão em Grão o Cerrado Perde Espaço. WWF-Brazil and PRÓ-CER. Brasília, DF, Brazil.

Magurran, A.E. (1998) Ecological diversity and its measurement. Princeton University Press, Princeton, NJ.

Marimon, B.S., Felfili, J.M. \& Lima, E.S. (2002) Floristics and phytosociology of the gallery forest of the Bacaba stream, Nova Xavantina, Mato Grosso, Brazil. Edinburgh Journal of Botany, 59, 303-318.

McCune, B. \& Mefford, M.J. (1999) PC-ORD, multivariate analysis of ecological data, Version 4. MjM Software Design, Glenden Beach, OR, USA.

Meinzer, F.C., Goldstein, G., Franco, A.C., Bustamante, M., Igler, E., Jackson, P., Caldas, L. \& Rundel, P.W. (1999) Atmospheric and hydraulic limitations on transpiration in Brazilian cerrado woody species. Functional Ecology, 13, 273282.

Mendonça, R., Felfili, J.M., Walter, B.M., Silva, M.C., Rezende, A.V., Filgueiras, T.S. \& Nogueira, P.E.N. (1998) Flora vascular do Cerrado. Cerrado: ambiente e flora (ed. by S. Sano and S. Almeida), pp. 289-556. EMBRAPA-CPAC, Planaltina, DF, Brazil.

Mistry, J. (1999) Population dynamics of the lichen genus Bulbothrix Hale as potential bioindicators of 'time-sincelast-fire' in the cerrado of the Distrito Federal, central Brazil. Diversity and Distributions, 5, 155-165.

Munhoz, C.B.R. (2003) Padrões de distribuição sazonal e espacial das espécies do estrato herbáceo-arbustivo em comunidades de campo limpo úmido e de campo sujo. Unpublished Doctorate Thesis, University of Brasília, Brazil.

Oliveira, R.A. (1999) Padrões sazonais de disponibilidade de água nos solos de um cerrado denso e um campo sujo e evapotranspiração. Unpublished Master's Thesis, University of Brasília, Brazil.

Ratter, J.A., Bridgewater, S. \& Ribeiro, J.F. (2003) Analysis of the floristic composition of the Brazilian Cerrado vegetation. III. Comparison of the woody vegetation of 376 areas. Edinburgh Journal of Botany, 60, 57-109.

Sampaio, A.B., Walter, B.M.T. \& Felfili, J.M. (2000) Diversidade e distribuição de espécies arbóreas em duas matas de galeria na micro-bacia do Riacho Fundo, Distrito Federal. Acta Botânica Brasílica, 14, 197-214.

Silva, L.B.Pda. (2003) Disponibilidade de água para as plantas e evapotranspiração em um cerrado denso, um cerrado strictu sensu e uma pastagem plantada. Unpublished Master's Thesis, University of Brasília, Brazil.

Silva, J.M.C. \& Bates, J.M. (2002) Biogeographic patterns and conservation in the South American cerrado: a tropical savanna hotspot. BioScience, 52, 225-233. 
Silva, M.C., Felfili, J.M., Walter, B.M.T., Nogueira, P.E., Rezende, A.V., Morais, R.O. \& Nóbrega, M.G.G. (2001) Análise da flora arbórea de Matas de Galeria no Distrito Federal: 21 levantamentos. Cerrado: Caracterização e Recuperação de matas de galeria (ed. by J.F. Ribeiro, C.E.L. Fonseca and J.C. Sousa-Silva), pp. 143-191. EMBRAPA-CERRADOS, Planaltina, DF, Brazil.

\section{BIOSKETCHES}

Juan F. Silva is a Venezuelan savanna ecologist leading a research network on the ecology of tropical communities and global change sponsored by the InterAmerican Institute for Research on Global Change (IAI). His work focuses on plant population and community dynamics, effects of fire, land use and climate.

Mario R. Fariñas is a Venezuelan ecologist working on community structure and ecological determinants in tropical savannas and paramos. He is currently looking at biodiversity responses to geomorphological and altitudinal gradients using a spatially explicit approach.

Carlos A. Klink is a Brazilian ecologist working on land-use change and the structure and functioning of Brazil's cerrado savanna ecosystems and the effects of fire on the population biology of native cerrado grasses.

Jeanine Felfilli is a Brazilian forester working on phytogeography, monitoring of permanent plots, experiments on plant growth, conservation design and reclamation of degraded savanna (cerrado), gallery forest and tropical seasonal forests.

Editors: Peter Furley, John Grace and Patrick Meir.

This paper is part of the Special Issue, Tropical savannas and seasonally dry forests: vegetation and environment, which owes its origins to a meeting held at the Royal Botanic Garden, Edinburgh, in September 2003. 
Copyright of Journal of Biogeography is the property of Blackwell Publishing Limited and its content may not be copied or emailed to multiple sites or posted to a listserv without the copyright holder's express written permission. However, users may print, download, or email articles for individual use. 